\title{
HISTOPATHOLOGICAL, CLINICO-BIOCHEMICAL AND THERAPEUTIC STUDIES ON DIFFERENT TYPES OF MANGE IN DOMESTIC RABBITS
}

\author{
RANIA I. MOHAMED ${ }^{1}$; DALIA IBRAHIM MOHAMED ${ }^{2}$; MUSTAFA KHALIL ${ }^{3}$; \\ NABILA M. EL MASRY ${ }^{4}$ and NESMA RASHEED ${ }^{1}$ \\ ${ }^{1}$ Department of Pathology, Animal Health Research Institute, Agriculture Research Center, \\ Egypt, Mansoura Provinicial Lab. \\ ${ }^{2}$ Department of Biochemistry, Animal Health Research Institute, Agriculture Research Center, \\ Egypt, Zagazig Provinicial Lab. \\ ${ }^{3}$ Department of Poultry Diseases, Animal Health Research Institute, Agriculture Research Center, \\ Egypt, Mansoura Provinicial Lab. \\ ${ }^{4}$ Department of Parasitology, Animal Health Research Institute, Agriculture Research Center, \\ Egypt, Mansoura Provinicial Lab.
}

Received: 31 December 2016; $\quad$ Accepted: 19 January 2017

\begin{abstract}
Mange is one of the serious injuries caused by Ectoparasites like Sarcoptes scabiei and Psoroptes cuniculi and the most frequently found in rabbit farms and results in considerable loss of weight, productivity, and fur quality. Several strategies have been proposed for the treatment of mange caused by these mites, ranging from the use of acaricides, drugs and chemicals such as ivermectin, which involves disadvantages including genotoxic and cytotoxic effects, resistance and environmental damage. In this study, we examined the oxidative status of the peripheral blood of rabbits infested with Psoroptes cuniculi and Sarcoptes scabiei and investigated the pathogenesis of this disease. Moreover, comparative study between the the therapeutic effects of topical application of propolis ointment $10 \%$ and subcutaneously injected ivermectin in naturally infested rabbits with Sarcoptes scabiei and Psoroptes cuniculi was done. Parasitological examination of ear wax and body scraping revealed the presence of living movable stages of both Sarcoptic and Psoroptic mites. However, microscopical examination of skin scraping and ear wax collected from treated rabbits after 10 days post treatment were negative for adult mites and its developmental stages. Hematological analysis revealed that RBCs count and PCV \% values in infested rabbits were decreased significantly $(\mathrm{P}<0.05)(2.2 \pm 0.1)$ and $(14 \pm 2.3)$ respectively than control group $(4.8 \pm 0.2)$ and $(31.8 \pm 3.8)$ respectively. Treatment with ivermectin and propolis were restored both RBCs count and PCV \% values significantly $(4.3 \pm 0.2)$ and $(21.5 \pm 2.2)$ respectively. Levels of lipid peroxides and malonyldialdehyde (MDA) were significantly higher in the mange infested rabbits compared with the healthy controls while those of the antioxidant enzymes glutathione-S-transferase (GST), and superoxide dismutase (SOD) were significantly lower. Treatment with ivermectin and propolis recovered these peroxides and antioxidant enzymes to approximately normal level. Regarding biochemical analysis, the levels of Aspartate Amino Transferase (AST) and Alanine Amino Transferase (ALT) in rabbits treated with ivermectin and propolis were decreased significantly $(\mathrm{P}<0.05)$ than those of rabbits of the positive control group. Histopathological examination of skin of infested rabbits revealed hyperkeratosis, acanthosis, subepidermal dermatitis and leukocytic infiltrations. Treated groups showed improvement in skin lesions manifested by reduction or absence of scales and mite stages. It was concluded that significant alteration of oxidant/antioxidant balance is a factor in the pathogenesis of mange infestation of rabbits, and recovery can be enhanced by ivermectin treatment and topical application of propolis.
\end{abstract}

Key Words: Sarcoptes scabiei, Psoroptes cuniculi, Rabbits, Ivermectin, Propolis, Histopathology.

\section{INTRODUCTION}

Sarcoptic mange, belongs to the family sarcoptidae is infectious disease which can threaten human and animal health globally (Alasaad et al.,

Corresponding author: Dr. RANIA I. MOHAMED

E-mail address: dr_raniaibrahem@yahoo.com

Present address: Department of Pathology, Animal Health Research Institute, Agriculture Research Center, Egypt, Mansoura Provinicial Lab
2011). In Egypt, mange (Sarcoptes and Psoroptes) in rabbits considered to be second to coccidiosis importance with high losses. (Ezzat, 1955). This dermatological Problems is occurred due to hot and humid climates (Aulakh et al. 2003). Moreover, overcrowded living conditions and Poor hygiene are significant factors for infestation by Sarcoptes mites (Mc Carthy et al., 2004). Mites generally spread from rabbit to rabbit by direct skin contact between infested and non infected rabbits or, through contact 
with the environment (Panigrahi and Gupta, 2013). Severe infestation especially in young or debilitated animals cause high mortality (Bornstein and Samuel, 2001). It characterized clinically by Pruritis, alopecia and prolonged illness. The animal become emaciated and may even die due to Cachexia. (Roy et al., 2001). Sarcoptes Scabiei is a deep burrowing mite in epidermis causing intense itching, purities, pyodermatitis, crust formation, Scar production, thickening of skin of affected areas, it causes infestation which affects ears, nose and feet beside area around genitalia, (Kachhawa et al., 2013). Psoroptes cuniculi, causes infestation primarily in the ears (Kyung-Yeon and Oh-Deog, 2010) which may cause extensive pyodermatitis in the ear or on the body surface of rabbit (Siegfried et al., 2004). It lives in the external auricular meatus where it is may fed on the serous exudate, skin secretion, and blood (Fichi et al., 2007 and Kyung-Yeon and Oh-Deog, 2010). Psoroptes mange is characterized by hypersensitivity reaction by the host to mite antigenic material causing inflammation, surface exudation, severe puritis, anorexia emaciation, fur loss, restlessness, biting and scratching of affected areas.

In severe cases, it causes meningitis and may be fatal when complicated by secondary bacterial pathogens (Kyung -Yeon and Oh-Deog, 2010 and Shang et al., 2014).

Two forms of P.cuniculi infestation are recognized in rabbits: i) typical Psoroptic (ear canker) which is confined to the ear canal and the pinnae ii) extra auricular mange, spreading over the body of the rabbits (Bates, 1999). Infestation may be chronic or even subclinical. In recent years attention has been focused on the use of Propolis as health supplement (Bankova, 2005).

Several strategies have been directed for treatment of mange caused by $P$. cuniculi, ranging from the use of acaricides, and essential oils, to vaccines (George et al., 2014). However, therapy and control of both human scabies and animal mange are still based mainly on the use of drugs and macrocyclic lactones such as ivermectin, selamectin, moxidectin, and eprinomectin (Wen et al., 2010 and Borges et al., 2013). The use of drugs, such as ivermectin has disadvantages, since it has both, genotoxic and cytotoxic effects. In addition, their widespread use induces resistance, accompanied by environmental pollution (Coles and Dryden, 2014). Such side effects of chemical acaricides have prompted a search and research efforts to discover new alternatives and effective compounds (Khater et al., 2013).

It is known that when reactive oxygen species (ROS) generation over-leads the antioxidant defense, the free radicals can then interact with endogenous macromolecules and alter the cellular functions (Muthukumaran et al., 2008). Free radicals and oxidative stress are involved in the pathogenesis of various diseases (Sies and Krinsky, 1995) including sarcoptic mange and Psoroptes mite (Gurgoze et al., 2003). However to our knowledge, whether $P$. cuniculi infestation causes oxidative stress or not has not been reported.

Propolis (bee glue) is a resinous hive product collected by honey bees from exudates and buds of plants and mixed with wax and bee enzymes (Burdock, 1998). Propolis has various biological and pharmacological properties, which had been associated with the presence of flavonoids and aromatic acids and esters (Salomao et al., 2004). Propolis possessed variable biological activities as antimicrobial (Abd El Hady and Hegazi, 2002), antiinflammatory (Park and Kahng, 1999), antioxidant (Kanbur et al., 2008), antiparasitic (Hegazi et al., 2007) antibacterial (Hegazi and Abd El Hady, 2002); fungicidal (Hegazi et al., 2000); antiulcer and antitumor (Hegazi et al., 1998).

Therefore, the present work was conducted to evaluate the therapeutic effect of $10 \%$ propolis ointment (as a local immunostimulant) against naturally infested rabbits with both body mange (Sarcoptes scabiei) and ear mange (Psoroptes cuniculi) in comparison with subcutaneously injected ivermectin. Hematological, biochemical, and histopathological investigations were done to check the propolis effect.

\section{MATERIALS AND METHODS}

\section{Animal Used.}

Forty male Commercial rabbits of different breeds (New Zealand and Baladi), their weights of 1.5-2 kg and 3-8 months old were used in this experiment. All rabbits were fed on balanced rations and a clean source of water ad libitum. The sampling procedures adhered to institutional ethical and animal care guidelines, and all methods were conducted in accordance with the Guide for the Care and Use of Laboratory Animals, according to Nong et al. (2013). Ten of these animals were healthy, allocated to the control group and the remaining 30 were naturally infested by Psoroptes cuniculi and Sarcoptic scabiei were obtained from some farm affected by an outbreak. The severity of the infection was determined according to clinical and laboratory examination and the scoring system described by Ulutas et al. (2005).

\section{Topical use of Propolis.}

$10 \%$ propolis ointment prepared by adding $10 \mathrm{gm}$ propolis to $90 \mathrm{gm}$ soft paraffin then used as topic for 3 successive days according to Abd El Aal (2005).

\section{Experimental design}

Rabbits were classified into four groups (ten rabbits each). The first group (group 1) was designated as the healthy or negative control group (non-infested by 
sarcoptic scabiei or psoroptic cuniculi mites and nontreated). Each rabbit in groups 2, 3, and 4 was naturally infested with Psoroptes cuniculi and Sarcoptic scabiei. The second group (group 2) was not treated and taken into account as the positive control group. The third group (group 3) was subcutaneously injected with ivermectin (IVR) $1 \%$ (Ivomec $®$, Merk Sharp and Dohme Agvet Inc.) two doses one week in between, at dose $400 \mu \mathrm{g} / \mathrm{kg}$ according to Galdhar et al. (2015). Finally, group 4 was treated topically with $10 \%$ propolis ointment for three successive days, according to Abd El Aal (2005)

\section{Erythrogram and Biochemical Analysis.}

Two blood samples were obtained from the ear vein of each rabbit after 10 days post treatments. The first sample was anticoagulated and used for the determination of the erythrocytes count, packed cell volume, hemoglobin concentration, and leucocytes by using Coulter (MEDONIC CA620) according to Feldman et al. (2000). The second sample was collected for serum separation and determination of serum biochemical constituents. Aspartate aminotransferase (AST) and Alanine Aminotransferase (ALT) were determined on semiauto-analyzer (Microlab-300, Merck) using commercial diagnostic kits manufactured by Merck (Reitman and frankel, 1957). Plasma malondialdehyde (MDA) levels were determined as described by Yoshioka et al. (1979); glutathione transferase (GST) was determined as described by Paglie and Valentie (1967) and superoxide dismutase SOD was assayed as described by Sun et al. (1988).

\section{Parasitological examination}

Skin scraping from body lesions and ear waxes were examined directly by microscope searching for moving living mange. The identification of the causative mite was carried out by preparation of permanent specimens using $10 \%$ sodium hydroxide in water bath for clearing from debris for fixation. The organisms were identified according to the keys of Baker et al. (1956) and Soulsby (1982).

\section{Clinical and pathological examinations}

Observations and recording of clinical signs, weight, and general conditions of control and infested and treated rabbits were done. Specimens from skin and ears of normal, clinically infested and treated rabbits( were collected after 10 days post treatment) and fixed in $10 \%$ neutral buffered formalin solution, dehydrated in gradual ethanol (70-100\%), cleared in xylene and embedded in paraffin. Five micron sections were prepared and then routinely stained with hematoxlyin and eosin (H\&E) according to Suvarna et al. (2013), then examined microscopically.

\section{Statistical analysis}

Data were analyzed using the one way variance of analysis (ANOVA) test and Duncan test according to Snedecor and Cochran (1982).

\section{RESULTS}

\section{Parasitological results:}

Result in table (1) revealed that out of 200 examined rabbits, $30(15 \%)$ were infected with mange. The incidence of body mange was $4 \%$ and ear mange was $5 \%$, while the incidence of mixed infestation was $6 \%$ (Table2). Rabbits infested with both ear and body mange showed emaciation and scratch of lesions due to intense pruritis, which lead to presence of scabs or dried crusts.

Infestation with the mange Sarcoptic scabiei (Fig.1), Psoroptic cuniculi (Fig.2) from infested rabbits were diagnosed by skin scrapping and microscopically, the results were tabulated in Table3. The seasonal dynamics of mange among rabbits in winter and spring was $10 \%$ and $18.5 \%$ respectively. However, microscopically examination of skin scraping collected from treated parts after 10 days post treatment were negative for adult mites and its developmental stages.

Table 1: Prevalence of mange amonge rabbits.

\begin{tabular}{cccc}
\hline Total No. Exam. & -ve & +ve & Total infestation rate \% \\
\hline 200 & 170 & 30 & 15 \\
\hline
\end{tabular}

This variation of incidence might be attributed to different management in the rabbit farms as the mange is a disease of poor condition animals, and due to variation of strain resistance of rabbit to mange infestation.

Table 2: Incidence of ear, body and mixed infestation with mange amange rabbits.

\begin{tabular}{ccccccc}
\hline $\begin{array}{c}\text { Total No. Exam. } \\
\text { Infected }\end{array}$ & \multicolumn{2}{c}{ Ear mange } & \multicolumn{2}{c}{ Body mange } & \multicolumn{2}{c}{ Mixed infestation } \\
\cline { 2 - 6 } & No. & $\%$ & No. & $\%$ & No. & $\%$ \\
\hline 30 & 10 & 5 & 8 & 4 & 12 & 6 \\
\hline
\end{tabular}


Table 3: Seasonal dynamics of mange amonge rabbits in two seasons.

\begin{tabular}{cccc}
\hline Season & No. of exam. rabbit & + ve & Total infestation rate \\
\hline Winter & 80 & 8 & $10 \%$ \\
\hline Spring & 120 & 22 & $18.3 \%$ \\
\hline
\end{tabular}

The prevalence of rabbit mange also varied seasonally in our study this variation might be attributed to the favorable temperature and humidity in spring.

\section{Hematological Results:}

Rabbits infested with Sarcoptes and Psoroptes showed a significant decrease in RBCs count and PCV \%values, while WBCs count exhibited significant increase compared to control group. Along the period of treatment, no significant changes were demonstrated in the values of $\mathrm{Hb}$ content (Table 4). Treatment with ivermectin and topically application of propolis recover RBCs count, PCV and WBCs count to normal level after 10 days post treatments.

Table 4: Erythrogram in different group of rabbits infested with mange and treated with either ivermectin or propolis (Mean $\pm \mathrm{SE}, \mathrm{n}=5$ )

\begin{tabular}{ccccc}
\hline Group & $\begin{array}{c}\text { RBCS } \\
\left(10^{6} / \mathrm{mm}^{3}\right)\end{array}$ & $\begin{array}{c}\text { Hb } \\
(\mathrm{gm} / \mathrm{dl})\end{array}$ & $\begin{array}{c}\text { PCV } \\
\%\end{array}$ & $\begin{array}{c}\text { WBCs } \\
\left(10^{3} / \mathrm{mm}^{3}\right)\end{array}$ \\
\hline Control & $4.8 \pm 0.2$ & $10 \pm 0.7$ & $31.8 \pm 3.8$ & $8 \pm 1.1$ \\
\hline Diseased & $2.2 \pm 0.1^{*}$ & $7.9 \pm 0.9$ & $14 \pm 2.3^{*}$ & $16.5 \pm 1.6^{*}$ \\
\hline Ivermectin treated & $4.3 \pm 0.2 \#$ & $8.5 \pm 0.5$ & $21.5 \pm 2.2 \#$ & $8.5 \pm 0.7 \#$ \\
\hline Propolis Treated & $4.5 \pm 0.1 \#$ & $8.9 \pm 0.5$ & $23.5 \pm 2.2 \#$ & $9.2 \pm 0.2 \#$ \\
\hline
\end{tabular}

Values are means \pm standard error $(\mathrm{SEM})$ for 5 different rabbits per each treatment. Values are statistically significant at $* \mathrm{p}<0.05 \mathrm{Vs}$. control; \#p<0.05 Vs. diseased.

\section{Antioxidant results}

Rabbits infected with Psoroptes cuniculi and Sarcoptic scabiei showed a decrease in antioxidant enzyme levels SOD and GST but exhibited an increase in MDA compared to normal rabbits as shown in Table (5). Treatment with both ivermectin and propolis restored these parameters to normal level after 10 days post treatment.

Table 5: SOD, GST and MDA levels in plasma of rabbits infested with mange and treated with either ivermectin or propolis (Mean \pm SE, $n=5$ ).

\begin{tabular}{cccc}
\hline Group & $\begin{array}{c}\text { SOD } \\
(\mathrm{U} / \mathrm{L})\end{array}$ & $\begin{array}{c}\text { GST } \\
(\mathrm{U} / \mathrm{L})\end{array}$ & $\begin{array}{c}\text { MDA } \\
(\mathrm{nmol} / \mathrm{L})\end{array}$ \\
\hline Control & $333.7 \pm 2.1$ & $193.6 \pm 3.2$ & $9.9 \pm 0.8$ \\
\hline Diseased & $227 \pm 8.0^{*}$ & $116 \pm 3.3^{*}$ & $19 \pm 0.7^{*}$ \\
\hline Ivermectin treated & $271.6 \pm 4.5 \#$ & $186.3 \pm 5.5 \#$ & $10.5 \pm 0.3 \#$ \\
\hline Propolis Treated & $294.3 \pm 3.8 \#$ & $188.6 \pm 6.1 \#$ & $11.2 \pm 0.6 \#$ \\
\hline
\end{tabular}

Values are means \pm standard error $(\mathrm{SEM})$ for 5 different rabbits per each treatment. Values are statistically significant at $* \mathrm{p}<0.05$ Vs. control; \# $<<0.05$ Vs. diseased.

\section{Biochemical Reults}

Table 6. presented significant increase in liver enzymes AST and ALT in rabbits infected with Psoroptes cuniculi and Sarcoptic scabiei however treatment with either ivermectin or propolis resulted in restoration in biochemical parameters to normal level. 
Table 6: ALT and AST levels in serum of rabbits infested with mange and treated with either ivermectin or propolis (Mean $\pm \mathrm{SE}, \mathrm{n}=5$ ).

\begin{tabular}{ccc}
\hline Group & ALT & AST \\
& $($ IU/L $)$ & $($ IU/L $)$ \\
\hline Control & $66.3 \pm 2.8$ & $\mathbf{2 6} \pm 2.1$ \\
\hline Diseased & $\mathbf{1 0 5} \pm 6.1^{*}$ & $\mathbf{5 0} \pm 2.9^{*}$ \\
\hline Ivermectin treated & $\mathbf{9 6} \pm 7.8 \#$ & $39 \pm 3.5 \#$ \\
\hline Propolis Treated & $\mathbf{7 2 . 7} \pm 4.1 \#$ & $\mathbf{3 4 . 6} \pm 2.9 \#$ \\
\hline
\end{tabular}

Values are means \pm standard error $(\mathrm{SEM})$ for 5 different rabbits per each treatment. Values are statistically significant at $* \mathrm{p}<0.05 \mathrm{Vs}$. control; \#p<0.05 Vs. diseased.

Clinical and Pathological results: 1. Body mange (Sarcoptes scabiei) infestation:

\section{A- Clinical signs and necropsy findings:}

Multifocal areas of alopecia areas containing scales were seen scattered on legs, face, lips, nose, ears, eyelid and fur (fig. 3-6). The infected rabbits were emaciated and showing scratching of the lesions due to intense pruritis. Greyish or whitish exudate, scabs or dried crusts sometimes could be seen. The morbidity and mortality rate among infected breeding flocks ranged from 5-8 \% and $0.5-2 \%$ respectively. Necropsy showed scales, crust formation, scar production, thickening of skin of affected areas with tunnels formation.

\section{B- Microscopically:}

Lesions characterized by hyperkeratosis, acanthosis and subepidermal dermatitis. Excess keratin production, with necrotic debris and sloughed epithelia mixed with developmental stages of the parasite could be seen on the body surface and within epidermal burrows (Fig.7 \& 8). Hyperplastic epidermal cells with formation of keratin cyst could be seen. Sometimes bacterial colonies could be seen in exudate and epidermal tissues. Intense dermatitis manifested by leukocytic infiltrations mainly lymphocytes, macrophages, together with hyperplastic sebaceous glands and dilated blood vessels were noticed (Fig, $9 \&$ 10). A few heterophilic infiltrations and hemorrhages could be seen accompanied by exfoliation of the epidermis.

\section{After 10 days post treatment:}

A clinical and macroscopic findings of treated rabbits showed improvement in skin lesions begins from 3rd days post treatment with either ivermectin or propolis manifested by reduction or absence of scales, mite stages (adult nymphs, larvae and eggs) and beginning of healing which usually nearly completed after 10 days.

Microscopic picture, (10 days post treatment) by ivermectin or propolis:

Pathological findings in treatment by ivermectin or propolis showing similar findings represented by regenerated skin.
Thin epidermal celayers were regenerated together with edematous dermal fibrous tissue containing little inflammatory cells mainly lymphocytes. In addition skin adnexa usually seen replaced the majority of the skin lesions (Fig,11 \& 12) were observed in both ivermectin or propolis treatment.

\section{Ear mange infestation (Psoroptes cuniculi):}

\section{A- Clinical signs and gross lesions:}

The disease was seen as sporadic cases among infected breeding and laboratory flocks, the infected rabbits revealed pruritus with scratching of the ears and head. Grayish, dry foul smelling exudate usually seen inside the ears. Other rabbits had thickened crusts which obstruct ear canal. The adjacent skin usually inflamed, ulcerated or scaly.

\section{B-Microscopically:}

Parasitic elements embedded within exudate from necrotic debris and inflammatory cells or free on the ulcerative surface and surrounded by intense inflammatory cells infiltration in subepithelial tissues (Fig, 13). The adjacent epidermal cells were hyperplastic with parakeratotic and acanthotic changes. Sometimes, parasites penetrate deeper in skin and underlying structures of the ear. Subepidermal tissues were edematous and highly infiltrated with lymphocytes and heterophils together with extravasated erythrocytes (Fig, 14).

\section{After 10 days post treatment:}

Nearly the same results were observed when using propolis and ivermectin. Gross mites reduction and complete absence of exudate from ear canal and mite stages.

Microscopic picture (10 days post treatment) by Ivermectin or propolis:

The majority of skin lesions showed mature fibrous tissues with islands from inflammatory cell aggregations and dilated blood vessels beside skin adnexa covered by several layers from non keratized epidermal cell layers, these pathological findings showed similar findings in treatment either by ivermectin or propolis as described in (Fig. 15\&16). 


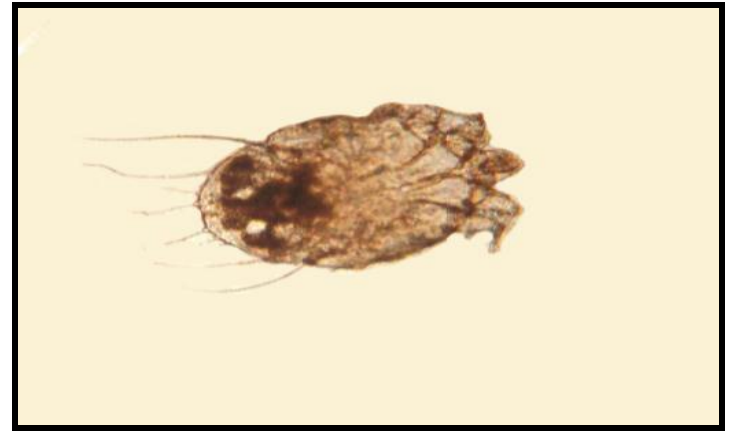

Fig. (1): Living movable adult stages of Sarcoptic mite in skin scraping of infested rabbits.

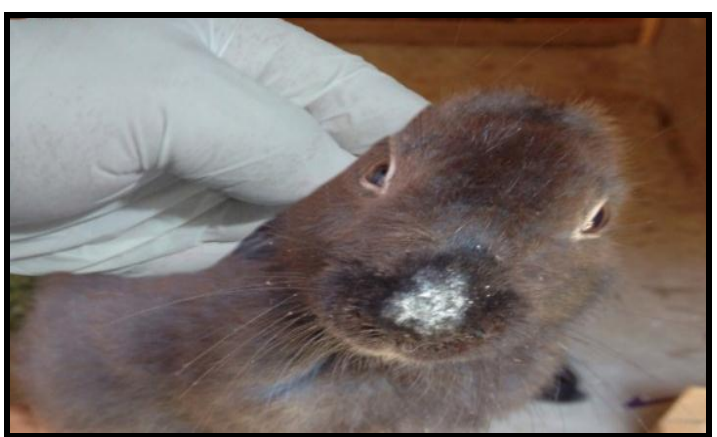

Fig. (3): Baladi rabbit showing focal areas of alopecia nose together with crust formation

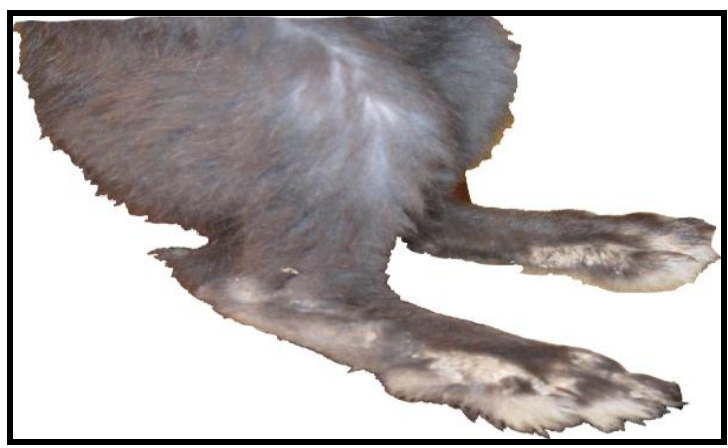

Fig. (5): Baladi rabbit showing multifocal areas of alopecia on legs together with crust formation

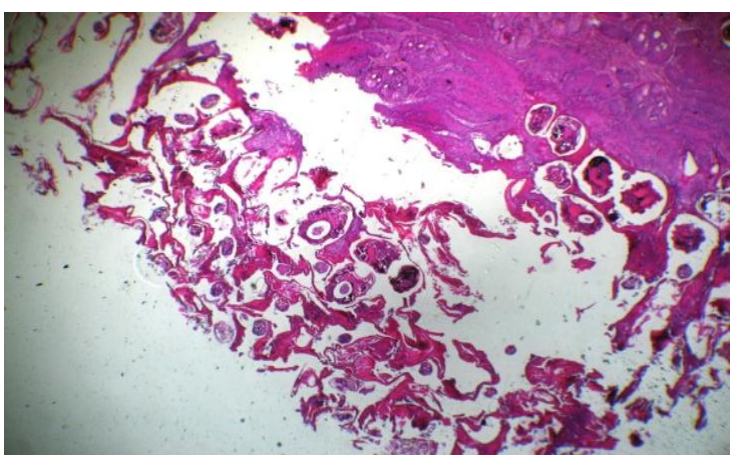

Fig. (7): Skin of rabbit (Sarcoptic mange) showing parasitic elements mixed with thickened keratin, sloughed epithelium and necrotic debris on tissue surface and within epidermal burrows. H\&E X 120.

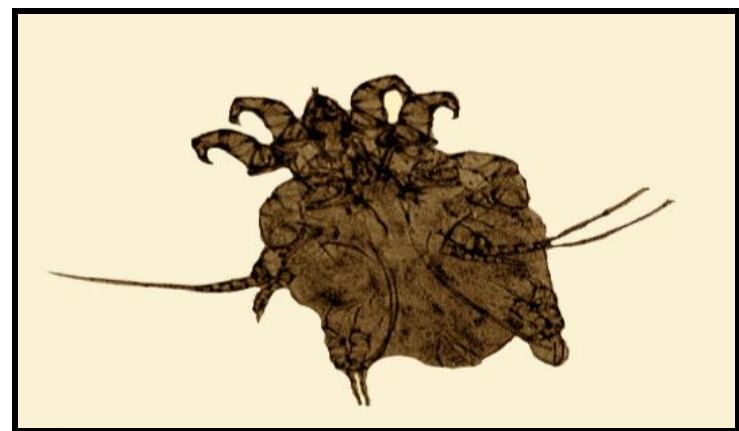

Fig. (2): Movable adult stage of Psoroptic mite in ear wax of infested rabbit.

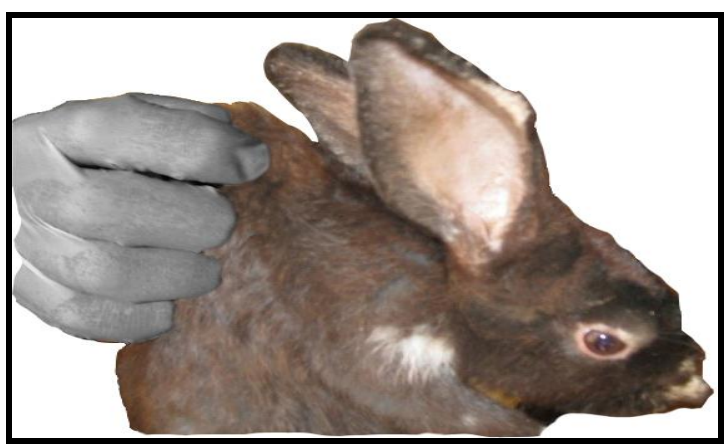

Fig. (4): Baladi rabbit showing multifocal areas of alopecia on nose, around eye and ears together with crust formation

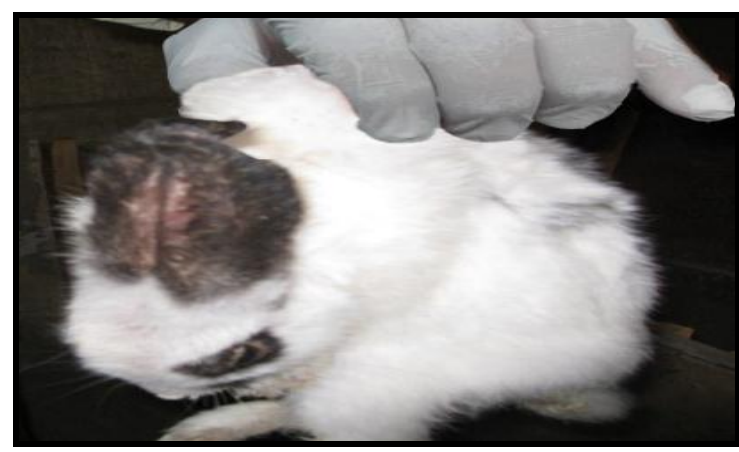

Fig. (6): Baladi rabbit showing severe emaciation, multifocal areas of alopecia on legs and ears together with crust formation

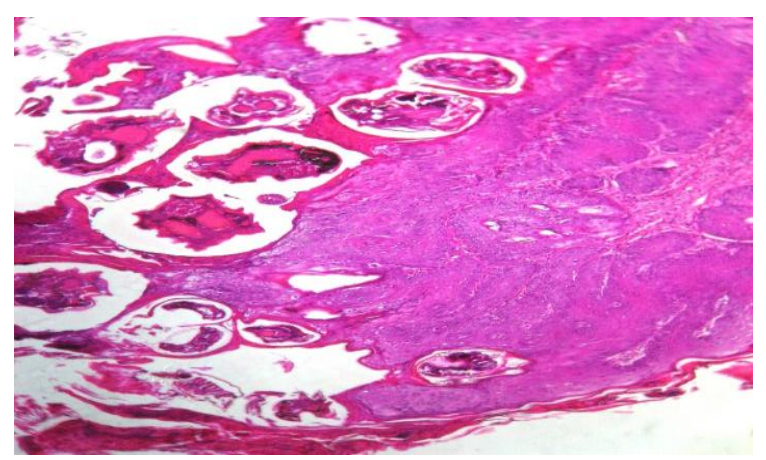

Fig. (8): High power of the previous figure to show epidermal burrows and parasitic elements beside parakeratotic and acanthotic skin $\mathrm{H} \& \mathrm{E} X$ 300 . 


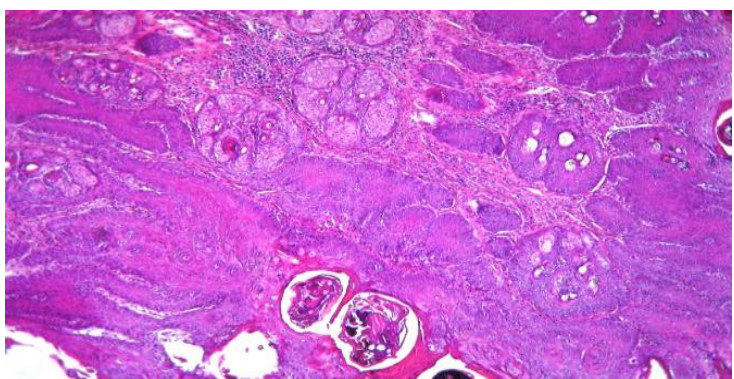

Fig. (9): Skin of rabbit (Sarcoptic mange) showing intense acanthosis beside hyperplastic sebaceous glands and leukocytic aggregations in dermis. H\&E $\mathrm{X} 100$.

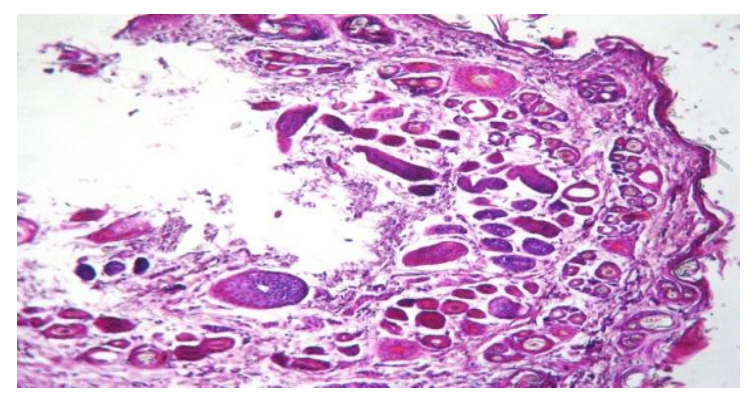

Fig. (11): Skin of rabbit 10 day post treatment of skin mange with ivermectin) showing regenerated and thin epidermal cell layers, edematous fibrous tissue of dermis covering majority of skin surface. H\&E X 50.

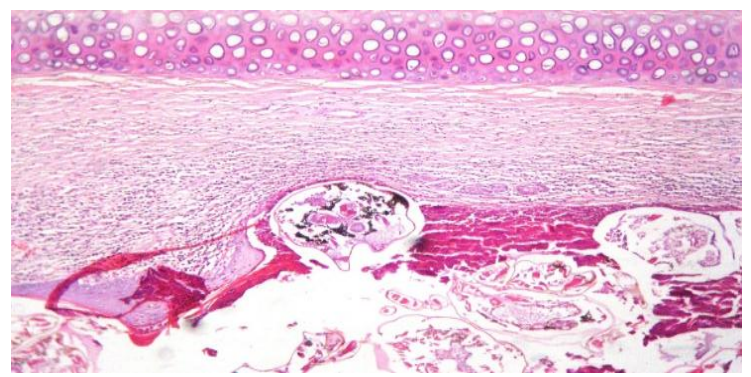

Fig. (13): Ear of rabbit (Otoacriasis) showing ulcerated skin with mite developmental stages mixed with exudate on skin of ear together with intense round cell infiltration and proliferation of fibroblast. H\&E X 100

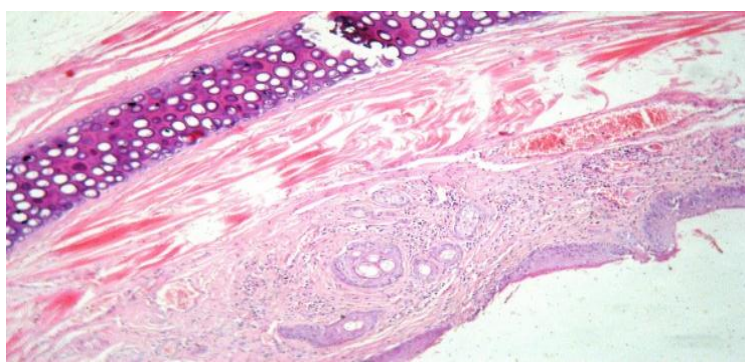

Fig. (15): Ear of rabbit (10 days post treatment with ivermectin) showing regenerated epidermal cell covering dermal mature fibrous tissue containing leukocytes and hyperemic blood vessels .H\&E X 100

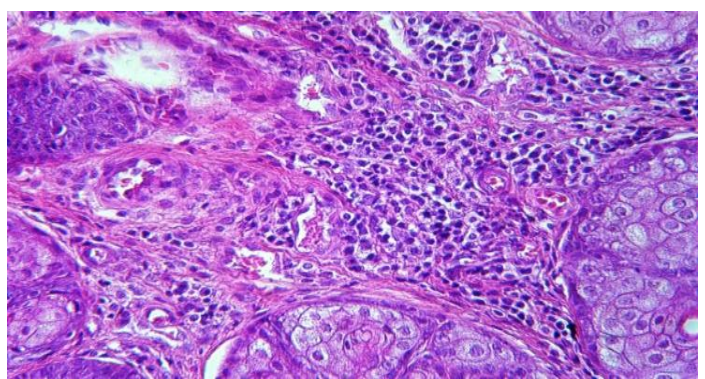

Fig. (10): High power of the previous figure to show hyperplastic sebaceous glands and interstitial mononuclear cell aggregations and fibrous tissue proliferation in dermis. H\&E X 600.

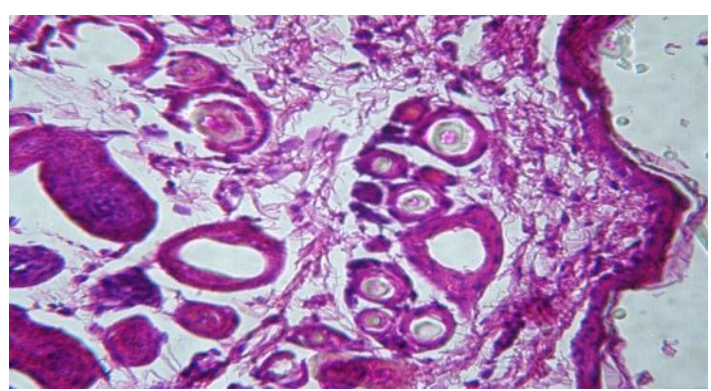

Fig. (12): High power of the previous figure to show a few epidermal cells and immature fibrous tissue and edema in dermis. H\&E $X$ 200.

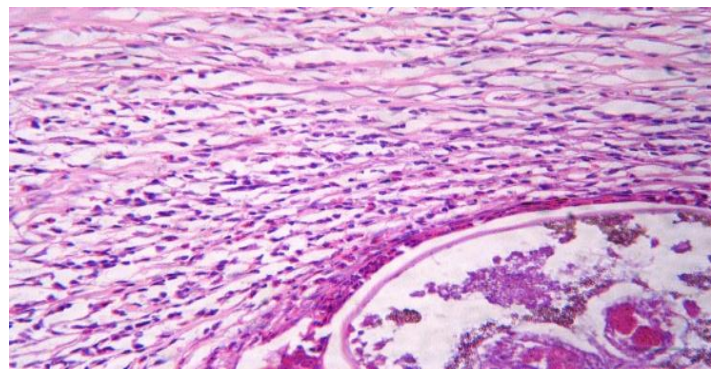

Fig. (14): High power of the previous figure to show mite embedded in skin surrounded by edematous fibrous tissue containing lymphocytes and extravasated erythrocytes. H\&E X400.

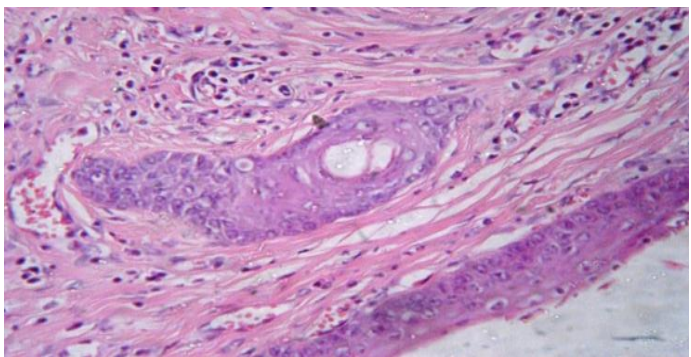

Fig. (16): High power of the previous figure to show non keratized stratified epithelium a mature fibrous tissue containing skin adnexa and little lymphocytes. H\&E X 400. 


\section{DISCUSSION}

Mange in rabbits due to Sarcoptes Scabiei or Psoroptes cuniculli considered a worldwide obligatory contagious ectoparasites (Perruci et al., 2005), which parasites on the surface of epidermis of rabbits causes pruritis and dermatitis, so it is classified as a major skin disease infest both young as well as adult rabbits (Siegmu, 1979).

Parasitological examination and skin scrapping revealed mange prevalence as $10 \%$ in winter while it was $18.3 \%$ in spring. These results were in agreement with Zelek and Bekele, (2001), and Smith, (2009), who mentioned that symptoms of mange were common during cold months. Regarding clinical signs and necropsy findings in infested rabbits showed characteristic skin lesions in most of the body parts accompanied emaciation and scratch lesions due to pruritis. These mites produce their pathologic effect by burrowing activity and mechanical damage during the excavation, Irritant action of their secretions and excretions while allergic reactions was resulted from extracellular products especially release of interleukin -1 (Wall and Shearer, 1997).

Crusted lesions contained large number of the parasite below the crusts are due to weak hypersensitivity reaction (Henry, 1996).

It is known that inflammatory cells are increased as a result of inflammation in rabbits with mange; recruited neutrophils and macrophages produce reactive oxidants such as hydrogen peroxide (H2O2), hypochlorite, and oxygen radicals. These reactive oxygen substances produced by cells of immune system showed potent cytotoxic effects on parasites and other pathogenic organisms (Gurgoze et al., 2003). Lipid peroxidation is well-established mechanism of cellular injury is used as an indicator of oxidative stress in cells and tissues. Lipid hydroperoxides are by-products of lipid peroxidation and increased levels of lipid peroxidation products are associated with variety of diseases such as parasitic infestations (Kiral et al., 2005). Lipid peroxidation can be harmful for skin due to alterations in the structure and permeability (Portugal et al., 2008).

The elevation in MDA levels in Psoroptes and Sarcoptic scabiei infested rabbits, the lipid peroxidemediated skin lesions. The decreased level of the body antioxidant (GSH) and reduced activities of the antioxidant enzymes for instance GST, CAT, and SOD imply that Psoroptes mite-infested rabbits are in a state of significant oxidative stress, and an altered antioxidant defense mechanism is under operation. States of oxidative stress have been demonstrated with various parasitic skin infestations including Sarcoptic mange (Saleh et al., 2011) and Psoroptic mange (Dimri et al., 2010).
Amelioration of the altered oxidant/antioxidant balance towards normal in ivermectin and propolis treated rabbits indicated potential antioxidant action of propolis. In the present study, we demonstrated both faster clinical and parasitological recovery in the ivermectin and propolis treated rabbits. Presented microscopical examination of skin scraping collected from treated parts after 10 days of treatment were negative for adult mites and its developmental stages and this in agreement with Amer and Abd El Aal (2005) who studied the effect of propolis in rabbits mange and found that use of $10 \%$ propolis ointment for 3 successive days resulted in complete reduction of clinical signs. Moreover, Garedew (2003) attributed these results to the acaricidal effect of propolis on body or ear mite, due to remarkable reduction in metabolic rates of mites. Presented results coincided with Garedew (2003) who stated that lethal effect of honey bees increased with increasing the concentration and the contact time achieving $100 \%$ mortality at $10 \%$ propolis concentration. Antioxidant vitamins in propolis generally enhance various aspects of cellular and noncellular immunity. $\beta$-carotene has significant antioxidant activity and can effectively quench the free radicals (Sharma and Sharma, 2009). As a hydrophobic antioxidant that incorporates into lipid environments, vitamin E significantly decreases lipid peroxidation in different organ and body fluid (Kara et al., 2008). Potential antioxidants include either natural free radical scavenging antioxidant enzymes or the agents which are capable of augmenting the activities of these enzymes, including the GSH-Px, GST, SOD, and CAT. In the current study, propolis treatment revealed potential enhancements in the antioxidant defense systems. The restoration of antioxidants and amelioration of lipid peroxidation in propolis treated rabbits might be involved in the faster clinical and parasitological cures.

Infested rabbits had higher MDA levels and lower GST and SOD levels than normal rabbits. This result indicated that $\mathrm{P}$. cuniculi infestation caused oxidative stress. The increase in MDA levels was most probably due to the increase in the biosynthesis of the enzyme caused by $\mathrm{H} 2 \mathrm{O} 2$ and other free radicals in P. cuniculi infestations; this is in agreement with Kanbur et al. (2008) who reported that Infestation stimulated oxidative stress. In the infested rabbits exposed to ivermectin and propolis, plasma MDA values decreased and GST and SOD levels increased, in comparison to values pertaining to non-treated rabbits. This phenomenon might be explained by the healing of infected rabbits following treatment with ivermectin and propolis. Singh et al. (2012) concluded that significant alteration of oxidant/antioxidant balance is a factor in the pathogenesis of $\mathrm{P}$. cuniculi infestation of rabbits, and recovery can be enhanced by combining ivermectin treatment with propolis supplementation. 
Regarding serum enzyme activities, AST and ALT showed significant gradual increase in infested rabbits along the period of experiment in comparison with control group. This result agreed with Talas and Gulhan (2009). The demonstrated result in the present study revealed that administration of propolis had no toxic effect on rabbit. A restoration in serum ALT and AST level was observed in propolis-treated groups; similar result was observed by Eraslan et al. (2007). Results of liver enzymes activities support that propolis able to induce hepatoprotective effects which are similar to those of the previous work on propolis that act as hepatoprotective against $d$ galactosamine, and paracetamol induced liver damage in rats and mice, respectively (Sugimoto et al., 1999).

The microscopic findings of body mange characterized by hyperkeratosis, acanthosis and subepidermal dermatitis, excess Keratin formation due to Sarcoptic mange results were in accordance with those obtained by Chandey et al. (2000) and Oraon et al. (2000).

Treated rabbits with ivermectin (400ug/k) showed improvement in skin lesions begins from the 3rd day post treatment leading to reduction or absence of scales and mite stages, this attributed to binding at ivermectin to glutamate gate and gamma-ammino butaric acid (GABA) gates chloride channels in the nervous system of mites resulting in hyper polarization of cells, Paralysis and finally death of mites. There results were in agreement with those obtained by Aulakh et al. (2003).

Rabbits infested with ear mange showed inflammation of skin, thekened crusts formation (Pruritic dermatitis), foul exudates inside the ear even obstruct the ear canal and loss at weight.

Psoroptes mites can complete their life cycle on the epidermis and then bore it, and feed on skin food and fluid. Skin fat resulted in release of toxins which lead to chronic allergy leading major injuries, scratching, reduce animal appetite and cause secondary infection (Joel and William, 1983).

Microscopic findings of ear mange showed hyperplasia, parakeratosis and acanthosis of the adjscent skin to ear, these results were similar to those obtained by Lossen et al. (1999).

Dermatitis of the thickened external ear is due to inflammatory cells infiltration, even ulcers and necrotic debris was created by three mechanisms:i) Part of the lesions is due to direct mechanical stimulation of the parasites and mucus from mange.ii) The allergic reaction that is created by immediate or delayed sensitivity in rabbits.iii). The damage that infested rabbits provides due to excessive itching and rubbing to objects.
After treatment with ivermectin, gross mites reduction occurred, and complete absence of exudate from ear canal. These findings were in agreement with Acar et al. (2007), as they successfully treated clinical signs manifested by rabbit with ivermectin.

It could be concluded that the efficiency of propolis ointment in treatment of Psoroptes cuniculi mite (ear mite) Sarcoptic scabiei which showed sluggish movement, stopped then lethal effect, Moreover, on the third day of treatment showed complete reduction of clinical lesions Garedew (2003) attributed these results to the acaricidal effect of propolis on body or ear mites, due to remarkable reduction in metabolic rates of mites. Presented results coincided with Garedew (2003) who stated that lethal effect of honey bees increased with increasing the concentration and the contact time achieving $100 \%$ mortality at $10 \%$ propolis ointment. Amer and Abdel Aaal (2005) augmented the present results that application of propolis ointment at $10 \%$ concentration resulting in complete reduction of clinical signs from the third day of treatment. They inferred that, the propolis extract succeeded to treat rabbit mange, so it was considered a good acaricidal.

\section{CONCLUSION}

We concluded that treatment of both types of mange in rabbits either by ivermectin $(400 \mu \mathrm{g} / \mathrm{kg})$ or $10 \%$ propolis ointment causes improvement of clinical signs, pathological lesions and biochemical parameters in infested rabbits. Moreover, microscopical examination of skin scraping collected from treated parts after 10 days of treatment were negative for adult mites and its developmental stages Thus, propolis can be used as an efficient and safe natural remedy for controlling mange in rabbits with avoidance the problems of chemical drugs.

\section{REFERENCES}

Abdel Aal, A.M.I. (2005): Effect of propolis on mange in rabbits. Egyptian vet. med. Society for parasitology 2(1): 293-304.

Abd El Hady, F.K. and Hegazi, A.G. (2002): Egyptian propolis: Chemical composition, antiviral and antimicrobial activities of East Nile Delta propolis," Zeitschrift fur Naturforschung C, 57 (3-4): 386-394.

Acar, A.; Kurtdede, A.; Ural, K.; Cingi, C.C.; Karakurum, M.C.; Yagci, B.B. and Sari, B. (2007): An ectopic case of Psoroptes cuniculi infection in a pet rabbit. Turk. J. Vet. Anim. Sci. 31(6): 423-425.

Alasaad, S.; Walton, S.; Rossi, L.; Bornstein, S.; AbuMadi, M.; Soriguer, R.C.; Fitzgerald, S.; Zhu, X.Q.; Zimmermann, W.; Ugbomoiko, U.S.; Chyi Pei, K.J. and Heukelbach, J. (2011): Sarcoptes-World Molecular Network 
(Sarcoptes-WMN): integrating research on scabies. Int. J. Infect. Dis. 15: e294-e297.

Amer, O.H. and Abdel-Aal, A.M.I. (2005): Effect of propolis on rabbit mange. EVMSPJ, 11(1): 293-304.

Aulakh, G.S.; Singla, L.D. and Singla, N. (2003): Pathology and therapy of natural notoedric acariosis in rabbits. J. Vet. Parasitol. 17: 127 129.

Baker, E.W.; Evans, T.M.; Gould, D.J.; Hull, W.B. and Keegan, H.C. (1956): A manual of the motes of New York; National pest control Association.

Bankova, V. (2005): Recent trends and important developments in propolis research. Evid. Bsed complement. Al ternat. Med. 2: 29-32.

Bates, P.G. (1999): Inter and intra-specific variation within the genus Psoroptes (Acari: Psoroptidae).Vet. Parasitol. 83, 201-217.

Borges, F.A.; Almeida, G.D.; Heckler, R.P.; Lemes, R.T.; Onizuka, M.K. and Borges, D.G. (2013): Anthelmintic resistance impact on tropical beef cattle productivity: effect on weight gain of weaned calves. Trop. Anim. Health Prod. 45(3): 723-7.

Bornstein, S.M.T. and Samuel, W.H. (2001): Parasitic diseases of wild mammals. Iowa state University Press. Ames. Iowa. 107-119.

Burdock, G.A. (1998): Review of the biological properties and toxicity of bee propolis (propolis)," Food and Chemical Toxicology. 36(4): 347-363.

Chandey, J.; Nambi, A.P.; Jeyaraja, K. and Gowri, B. (2000): Clinicopathological and biochemical studies in scabies in dogs. Indian Vet. J. 77, 755-757.

Coles, T.B. and Dryden, M.W. (2014): Insecticide/ acaricide resistance in fleas and ticks infesting dogs and cats. Parasit Vectors. 7: 8.

Dimri, U.; Sharma, M.C.; Yamdagni, A.; Ranjan, R. and Zama, M.M.S. (2010): Psoroptic mange infection increases oxidative stress and decreases antioxidant status in sheep, Veterinary Parasitology, 168 (3-4): 318-322.

Eraslan, G.; Kanbur, M. and Silici, S. (2007): Evaluation of propolis effects on some biochemical parameters in rats treated with sodium fluoride. Pesticide Biochemistry and Physiology. 88(3): 273-283.

Ezzat, M. (1955): External parasites of Egyptian animals. Second-Arab- Scientific-Congress, Cairo.

Feldman, B.F.; Joseph, G.; Zinkl, J.G. and Jain, N.C. (2000): Schalm's Veterinary Hematology. $5^{\text {th }}$ ed. Philadelphia, Pa, USA: Lippincott Williams and Wilkins.

Fichi, G.; Flamini, G.; Giovanelli, F.; Otranto, D. and Perrucci, S. (2007): Efficacy of an essential oil of E1cgenia caryophyllata agafnst Psoroptes cuniculli. Exp. Parasito 115: 168172.
Galdhar, C.N.; Khangal, P.S.; Pawar, M.L.; Rasal, T.D. and Digraskar, S.U. (2015): Clinicobiochemical and therapeutic studies on notoedric mange in pet rabbits. Parasit Dis., 39(1): 113-6.

Garedew, A. (2003): Microcalorimetric and microbiological in vitro investigations on the Acaricidal, Insecticidal and antimicrobial effects of propolis, Ph.D thesis Berlin.

George, D.R.; Finn, R.D.; Graham, K.M. and Sparagano, O.A. (2014): Present and future potential of plant-derived products to control arthropods of veterinary and medical significance. Parasit Vectors. 7: 28.

Gurgoze, S.Y.; Sahin, T.; Sevgili, M.; Ozkutlu, Z. and Ozan, S.T. (2003): The effect of ivermectin or doramectin treatment on someantioxidant enzymes and the level of lipid peroxidation in sheepwith natural sarcoptic scab, Yuzuncu Yil Universitesi Veteriner Facultesi Dergisi, 14: 30-34.

Hegazi, A.G.; Abd El Hady, F.K. and Shalaby, H.A. (2007): An in vitro effect of propolis on adult worms of Fasciolagigantica," Veterinary Parasitology, 144 (3-4): 279-286.

Hegazi, A.G. and Abd El Hady, F.K. (2002): Egyptian propolis: antioxidant, antimicrobial activity and chemical composition of propolis from reclaimed land. Z. Naturforsch 57c, 395402.

Hegazi, A.G.; Abd El Hady, F.K. and Abd Allah, F. (2000): Chemical composition and antimicrobial activity of European propolis. Z. Naturforsch 55c, 70-75.

Hegazi, A.G.; Moharm, N.Z.; Abd Allah, F.; El Sheikh, E.; Ellithy, N.A. and Khair, A.M. (1998): Influence of ethanolic extract of Egyptian propolis on immune status in mice bearing Ehrlich. J. Union of Arab Biologists 10 (A): 387-396.

Henry, J.B. (1996): Clinical diagnosis and management by laboratory methods. $9^{\text {th }}$ ed. WB Saunders Company Philadelphia London, Toronto, Montreal, Sydney, Tokyo

Joel, D.W. and William, J.B. (1983): Disease of Exotic Animals: Medical and Surgical Management. p. 134 (Wolf Medical Publication. Ltd., London). Validity of the species in Psoroptes, a genus of mange mite. Can. J. zc,ol. 36, 905-929.

Kachhawa, J.P.; Kachhawa, S.; Srivastava, M.; Chahar, A. and Singh, N.K. (2013): Therapeutic management in rabbits. Intas Polivet 14 (11): 306-308.

Kanbur, M.; Atalay, O.; Ica, A.; Eraslan, G. and Cam, Y. (2008): The curative and antioxidative efficiency of doramectinand doramectin + vitamin AD3E treatment on Psoroptes cuniculiinfection in rabbits. Research in Veterinary Science 85: 291-293. 
Kara, H.; Cevik, A.; Konar, V.; Dayangac, A. and Servi, K. (2008): Effects of selenium with vitamin $\mathrm{E}$ and melatonin on cadmium induced oxidative damage in rat liver and kidneys, Biological Trace Element Research, 125(3): 236-244.

Khater, H.F.; Seddiek, S.A.; El-Shorbagy M.M. and Ali, M.M. (2013a): The acaricidal efficacy of peracetic acid and deltamethrin against the fowl tick, Argaspersicus, infesting laying hens. Parasitol Res 112(1): 259-269.

Kiral, F.; Karagenc, T.; Pasa, S.; Yenisey, C. and Seyrek, K. (2005): Dogs with Hepatozooncanis respond to the oxidative stress by increased production of glutathione and nitric oxide, Veterinary Parasitology, 131(1-2): 15-21.

Kyung-Yeon, E. and Oh-Deog, K. (2010): Psoroptic otacariasis associated with Psoroptes cuniculli in domestic rabbits in Korea. Pak Vet. J. 30, 251-252.

Loossen, B.J.; Lonneux, J.F. and Lekimme, M. (1999): The Pathology of Psoroptes ovis infection in cattle with a special emphasis on breed difference. Veterinary Parasitol. 83: 219-229.

McCarthy, J.; Kemp, D.; Walton, S. and Currie, B. (2004): Scabies: more than just an irritation. Post Grad Med. J. 80: 382-387.

Muthukumaran, S.; Sudheer, A.; Menon, V.P. and Nalini, N. (2008): Protective effect of quercetin on nicotine-induced prooxidant and antioxidant imbalance and DNA damage in wistar rats. Toxicology, 243: 207-215.

Nong, X.; Ren, Y.; Wang, J.; Fang, C.; Xie, Y.; Yang, D.; Liu, T.; Chen, L.; Zhou, Z.; Gu, X.; Zheng, W.; Peng, X.; Wang, S.; Lai, S. and Yang, G. (2013): Clinical efficacy of botanical extracts from Eupatorium adenophorum against the scab mite, Psoroptes cuniculi. Vet Parasitol 192(1-3): 247-252.

Oraon, B.; Thakur, D.K.; Singh, S.K. and Gupta, M.K. (2000): Clinicopathological changes in pigs experimentally infected with Sarcoptes scabiei. Indian J. Anim. Sci. 70: 405-406.

Park, E.H. and Kahng, J.H. (1999): Suppressive effects of propolis in rat adjuvant arthritis. Arch Pharm Res., 22(6): 554-8.

Paglie, D.E. and Valentie, W.N. (1967): Studies on the quantitative and quantitative characterization of erythrocyte glutathione peroxidase. Journal of Laboratory Medicine 70: $158-169$.

Panigrahi, P.N. and Gupta, A.R. (2013): Therapeutic management of concurrent sarcoptic and psoroptic acariasis in rabbits. Intas Polivet 14 (11): 319-321.

Perruci, S.; Rossi, G.; Fichi, G. and Brien, D.J. (2005): Relationship between Psoroptes cuniculli and the internal bacterium serratia marcescens. Exp. Appl. Acarol. 36: 199-206.
Portugal, L.R.; Fernandes, L.R.; Pietra-Pedroso, V.S.; Santiago, H.C.; Gazzinelli, R.T. and Alvarez-Leite, J.I. (2008): Influence of lowdensity lipoprotein (LDL) receptor on lipid composition, inflammation and parasitism during Toxoplasma gondii infection, Microbes and Infection, 10(3): 276-284.

Reitman, S.M.D. and Frankel, S. (1957): A colorimetric method for the determination of serum glutamic oxalacetic and glutamic pyruvic transaminases, "The American Journal of Clinical Pathology, 28 (1): 56-63.

Roy, S.; Roy, M.; Dutta, G.K.; Pal, S. and Tewari, S.K. (2001): Therapeutic evaluation herbal preparations against domestic mange infection in dogs. Indian Vet J., 78: 629-630.

Saleh, M.A.; Mahran, O.M. and Al-Salahy, M.B. (2011): Circulatingoxidative stress status in dromedary camels infected withsarcoptic mange, Veterinary Research Communication, 35: 35-45.

Salomao, K.; Dantas, A.P.; Borba, C.M.; Campos, L.C.; Machado, D.G.; Aquino Neto, F.R. and de Castro, S.L. (2004): Chemical composition and microbicidal activity of extracts from Brazilian and Bulgarian propolis. Lett. Appl. Microbiol. 38: 87-92.

Seddiek, S.A.; Khater, H.F.; El-Shorbagy, M.M. and Ali, A.M. (2013): The acaricidal efficacy of aqueous neem extract and ivermectin against Sarcoptes scabiei var. cuniculi in experimentally infected rabbits. Parasitol Res., 112: 2319-2330.

Shang, X.; Wang, D.; Miao, X.; Wang, X.; Li, J. and Yang, Z. (2014): The oxidative status and inflammatory level of the peripheral blood of rabbits infected with Psoroptes cuniculi. Parasit Vectors, 7: 124.

Sharma, B. and Sharma, S.D. (2009): Antioxidants: tools to enhance livestock productivity, The Indian Cow, (Jan.-March), 3-15.

Siegfried, E.; Ochs, H. and Deplazes, P. (2004): Clinical development and serological antibody responses in sheep and rabbits experimentally infected with Psoroptes ovis and Psoroptes cuniculli.Vet Parasitol., 124: 109-124.

Siegmu, O.H. (1979): The Merck Veterinary Manual. $5^{\text {th }}$ ed. Merck and company. Inc. Ranway NJ. USA. 1184.

Sies, H. and Krinsky, N. (1995): The present status of antioxidant vitamins and beta-carotene. American Journal of Clinical Nutrition 62: 1299S-1300S

Singh, S.K.; Dimri, U.; Sharma, M.C.; Swarup, D.; Kumar, M. and Tiwary, R. (2012): Psoroptes cuniculi induced oxidative imbalance in rabbits and its alleviation by using vitamins $\mathrm{A}$, D3, E, and Has adjunctive remedial. Trop Anim Health Prod., 44:43-48. 
Smith, B.P. (2009): Large Animal lnternal Medicine. Fourth Ed. Mosby Elsevier, Printed in United States.

Snedecor, G.W. and Cochran, W.G. (1982): Statistical Methods. $8^{\text {th }}$ ed. Ames, Iowa, USA: Iowa State University Press.

Soulsby, E.J. (1982): Helminths, Arthropodes and Protozoa of Domestic Animals. $7^{\text {th }}$ Ed. Baillieri, Tindall, London.

Sugimoto, Y.; Tarumi, T.; Kaneko Y.; Isayama, S.; Kawai, N.; Sugimoto, H.; Yamada, H. and Kamei, C. (1999): Effect of propolis extract on D-galactosamine-induced hepatic injury in rats. Biological and Pharmaceutical Bulletin, 22 (11): 1237-1239

Sun, Y.; Oberley, L.W. and Li, Y. (1988): A simple method for clinical assay of superoxide dismutase. Clinical Chemistry 34, 497-500.

Suvarna, K.S.; Layton, C.H. and Banchroft (2013): Theory and practis of histological techniques. $4^{\text {th }}$ ed, newyork. churchill, Livingston.

Talas, Z.S. and Gulhan, M.F. (2009): Effects of various propolis concentrations on biochemical and hematological parameters of rainbow trout (Oncorhynchusmykiss), Ecotoxicology and Environmental Safety, 72 (7): 1994-1998.
Ulutas, B.; Voyvoda, H.; Bayramli, G. and Karagenc, T. (2005): Efficiency of topical administration of eprinomectin for treatment of ear mite infection in six rabbits. Veterinary Dermatology 16: 334-337.

Wall, R. and Shearer, D. (1997): Veterinary Entomology. $1^{\text {st }}$ ed. Chapman and Hall. London.

Wen, H.; Pan, B.; Wang, F.; Yang, Z.; Wang, Z.; Liu, $S$. and Wang, M. (2010): The effect of selflicking behavior on pharmacokinetics of eprinomectin and clinical efficacy against Psoroptes cuniculi in topically administered rabbits, Parasitology Research, 106(3): 607613.

Yoshioka, T.; Kawada, K.; Shimada, T. and Mori, M. (1979): Lipid peroxidation in material and cord blood and protective mechanism against activated-oxygen toxicity in the blood. American Journal of Obstetric and Gynecology 135: 372-376.

Zeleke, M. and Bekele T. (2001): Effect of season on the productivity of camels (Camelus dromedarius) and the prevalence of their major parasites in eastern Ethiopia. Anim Hlth. Prod.33: 321-329.

\section{دراسات باثولوجية ، كيميائية وعلاجية على أنواع الجرب المختلفة في الأرانب \\ رانيا إبراهيم محمد إبراهيم ، داليا إبراهيم محد إبراهيم ، مصطفى خليل ، نبيلة المصري ، نسمة رشبي}

Email: dr_raniaibrahem@yahoo.com Assiut University web-site: www.aun.edu.eg

الجرب هو واحد من الإصابات الخطيرة التي تسبيها أحد الطفيليات الخارجية مثل القارمة الجربية و القارشة الأرنبية والتي كثير التيا ما

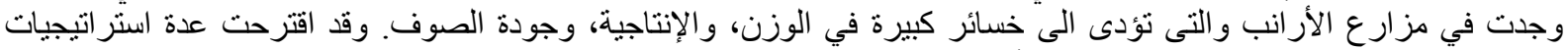

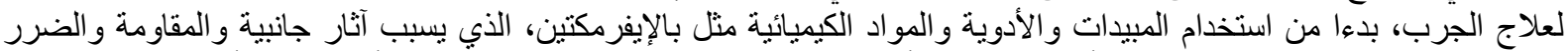

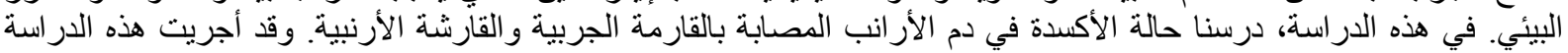

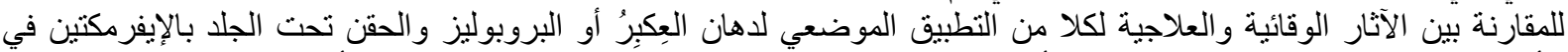

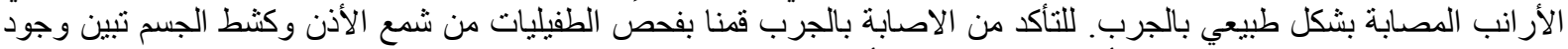

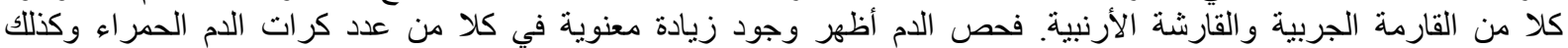

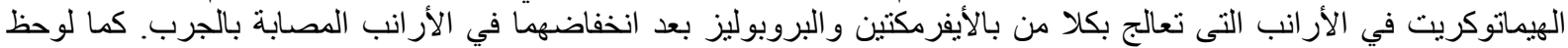

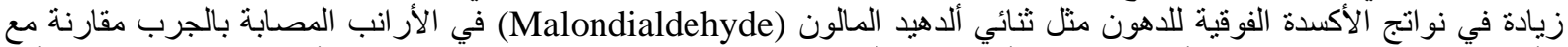

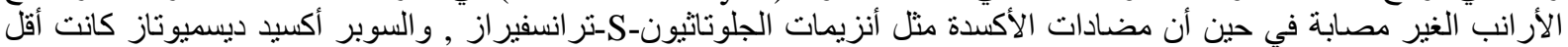

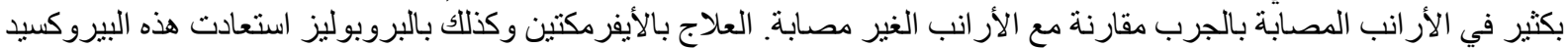

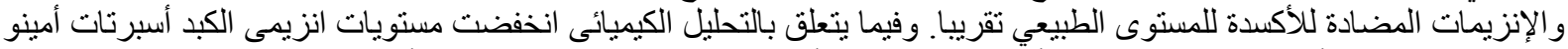

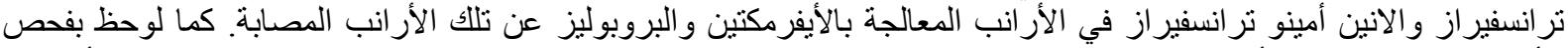

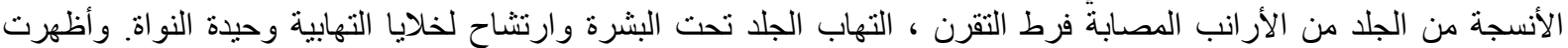

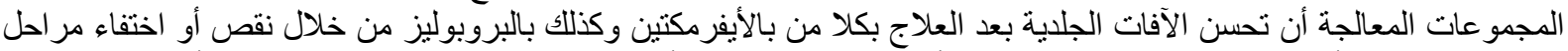

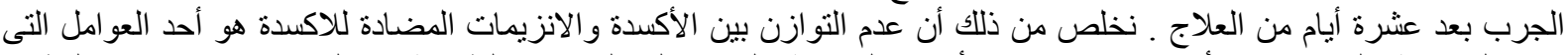

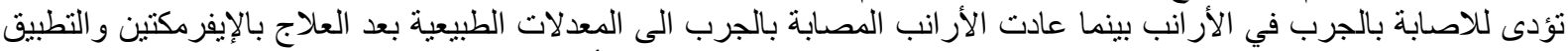
الموضعي للبروبوليز. لذا توصى الدراسة باستخدام البروبوليز لعلاج الجرب في الجي الأر انب كبديل طبيعى للادوية الكيميائية . 